\title{
Attachment of Bean Rust Cell Wall Material to Host and Non-Host Plant Tissue
}

\author{
Kurt Mendgen \\ Institut für Pflanzenpathologie und Pflanzenschutz der Universität, \\ Grisebachstr. 6, D-3400 Göttingen, Federal Republic of Germany
}

\begin{abstract}
A preparation of bean rust (Uromyces phaseoli) germ tube walls, consisting of short, filamentous particles, was labeled with fluorescein iso-thiocyanate. Freeze sections of host and non-host tissue were incubated in the labeled preparation. Maximum staining was observed in host plant tissue (Phaseolus vulgaris), in which bean rust regularly forms haustoria. In tissue of the non-host plants Vigna sinensis and Phaseolus lunatus, where fewer haustoria were formed, staining was only weak. However, no staining was observed in the non-host tissue of Phaseolus aureus, Helianthus annuus, Brassica oleracea and Hordeum vulgare in which the infection hypha did not form haustoria. This would appear to indicate that formation of haustoria is induced by a specific attachment of the hyphal wall to the host wall. The possibility that elicitors attach in a similar way, is discussed.
\end{abstract}

Key words: Bean rust - Uromyces phaseoli-Phaseolus vulgaris - Germ tube wall material - Cell walls Recognition - Elicitor - Specific attachment.

The cell envelope of many bacteria consists of polysaccharides that allow adhesion on particular locations in their natural environment (Sutherland, 1977; Costerton et al., 1978). Non-pathogenic bacteria which attach to plant cell walls may be enveloped by wall material and subsequently degraded (Goodman et al., 1976; Sequeira et al., 1977). Plant pathogenic bacteria, such as crown gall bacteria (Lippincott and Lippincott, 1969) or rhizobia (see Dazzo and Hubbel, 1975) are assumed to attach to an infectible site before entering the host. This attachment on a surface may be the result of an interaction of polysaccharide chains localised on

Abbreviations. Fluorescein iso-thiocyanate $=$ FITC; cultivar $=\mathrm{cv}$ the bacterial surface and lectins on the plant cell wall (see Kauss, 1977; Raa et al., 1977; Dazzo et al., 1978).

The bean rust germ tube wall contains polysaccharides with glucose, mannose and glucosamine as constituents. Polysaccharides were reported to be covalently bound to proteins (Trocha et al., 1974; Trocha and Daly, 1974). Similar results were obtained with germ tube walls of stem rust (Puccinia graminis) by Joppien et al. (1972).

Electron micrographs of rusts within a host leaf show an intimate contact between the plant and hyphal walls in the region of the haustorial mother cell and at the site of the fungus penetration peg. In this region, the wall of the host and the wall of the parasite seem to merge very often (Bracker and Littlefield, 1973). However, in non-host plants haustoria are usually not formed (Heath, 1974, 1977).

These results suggest that during the interaction between host plants and rusts a recognition process (attachment) between the host - and parasite wall may take place before the haustorium is formed. To study recognition processes between the host and fungal cell wall, a preparation of bean rust (Uromyces phaseoli [Pers.] Winter var. typica Arth.) germ tubes, labeled with fluorescein iso-thiocyanate, was incubated with the tissue of host and non-host plants to determine its differential attachment.

\section{Materials and Methods}

Phaseolus vulgaris L. (French bean) cvs Favorit, Golden Gate Wax and 017, Brassica oleracea var. gongyloides L. (kohlrabi) cv Blauer Delikatess, Vigna sinensis (Torner) Savi (cowpea), Phaseolus lunatus L. (limabean) cv P 13-3, Hordeum vulgare L. (barley) cv Rupée, Phaseolus aureus L. cv Jerusalembohne and Helianthus annuus L. (sunflower) cv Teddybär were grown in a growth chamber with about $4000 \mathrm{Lux}$ incandescent light $16 \mathrm{~h}$ per day, night temperature $12^{\circ} \mathrm{C}$ and day temperature about $18^{\circ} \mathrm{C}$.

Plants were inoculated with bean rust, Uromyces phaseoli (Pers.) Winter var. typica by spraying the leaves with a suspension of 
uredospores. The spores were washed in running water for $1 \mathrm{~h}$. After inoculation, the plants were incubated at $18^{\circ} \mathrm{C}$ in high humidity for $28 \mathrm{~h}$.

For the study of the rust infection, whole mounts of leaf tissue were cleared $28 \mathrm{~h}$ after inoculation in lactophenol cottonblue. Only sporelings which had formed an appressorium over the stoma and differentiated an infection hypha that had reached the middle of the leaf parenchyma were observed for formation of haustoria. At least, 50 infection hyphae per tissue were examined.

For the preparation of germ tube wall material $1.5 \mathrm{~g}$ uredospores were floated on 1001 water for $24 \mathrm{~h}$ at $20^{\circ} \mathrm{C}$. The spores with the germ tubes were collected, sonicated for $10 \mathrm{~min}$ in $100 \mathrm{ml}$ water with a Braun 300 Cell desintegrator at maximum power and centrifuged at $100 \times \mathrm{g}$. The dark brown pellet consisted mainly of uredospore walls and was discarded. The light grey supernatant was centrifuged for $10 \mathrm{~min}$ at $2,000 \times \mathrm{g}$. The pellet consisted of a white deposit of germ tube walls as checked with an interference contrast microscope. This deposit was washed in $50 \mathrm{ml}$ water, lyophilized, then extracted with $50 \mathrm{ml}$ chloroform-methanol $1: 2$, then with $50 \mathrm{ml}$ acetone. In both extraction steps, the material was sonicated for $2 \mathrm{~min}$ as described and then centrifuged at $4,000 \times \mathrm{g}$. The germ tube wall material, dried with nitrogen, had a dry mass of $20 \mathrm{mg}$. It was taken up in $1 \mathrm{ml}$ water and sonicated for $3 \mathrm{~min}$. In some experiments, this suspension was kept at $120^{\circ} \mathrm{C}$ for $1 \mathrm{~h}$. This last procedure had no major effect on the results

For electron microscope examination, the wall suspension was mixed 1:1 with $2 \%$ phosphotungstic acid, dropped on formvar coated grids and examined with a Zeiss EM 10 electron microscope at $80 \mathrm{kv}$.

Labeling of the cell wall material was performed by mixing $10 \mathrm{mg}$ wall material in $0.5 \mathrm{ml}$ water and adding $1 \mathrm{ml}$ carbonate buffer $(0.1 \mathrm{M}$, $\mathrm{pH} 9.5)$ and $0.5 \mathrm{ml} \mathrm{NaCl}(0.15 \mathrm{M})$ with $0.25 \mathrm{mg}$ fluorescein isothiocyanate (FITC). The pH was adjusted to 9.5 with $0.5 \mathrm{M} \mathrm{NaOH}$ and the suspension kept at $30^{\circ} \mathrm{C}$ for $3 \mathrm{~h}$. Then it was dialysed against $0.01 \mathrm{M}$ phosphate buffer $\mathrm{pH} 7.2$ with $0.15 \mathrm{M} \mathrm{NaCl}$ for 3 days at $4^{\circ} \mathrm{C}$ with buffer changes every $8 \mathrm{~h}$. This preparation could be used for about a week when kept in a refrigerator

Before incubation, stems of plants were fixed in $96 \%$ ethanol for $10 \mathrm{~min}$, washed in phosphate buffer with saline as above for $2 \mathrm{~h}$ and sectioned with a freezing microtome. $30 \mu \mathrm{m}$ thick sections were floated in the buffer or placed into the suspension of labeled wall material for $2-3 \mathrm{~h}$ at $25^{\circ} \mathrm{C}$. Then, the incubated sections were thoroughly washed in the buffer.

Both, incubated and non-incubated sections were placed together on microscope slides and examined in a Leitz fluorescence microscope. An excitation filter with $390-490 \mathrm{~nm}$ transmission and a barrier filter up to $515 \mathrm{~nm}$ were used. The non-incubated (on the left) and the incubated (on the right) sections were photographed together with Kodak Ektachrome 200 color film.

\section{Results and Discussion}

In compatible and incompatible combinations of bean (Phaseolus vulgaris) and bean rust (Uromyces phaseoli), the germ tube forms an appressorium over the stoma, enters the substomatal cavity and differentiates an infection hypha. This infection hypha comes into contact with a mesophyll cell and forms there a haustorium mother cell to penetrate and develop the first haustorium (Mendgen, 1978). After the haustorium is fully developed, different reaction sequences of compatibility or incompatibility between host and parasite begin (Mendgen, 1978).

In non-host plants, the bean rust also penetrates into the leaf mesophyll, although with lower efficiency (Mendgen, unpublished). Obviously, differences in the structure of the epidermis and the stomata reduce the ability of the fungus to penetrate into the leaf. Similar results have been obtained with the cowpea rust (Heath 1974, 1977), which behaves like bean rust.

In the present investigation only a few haustoria were formed in the parenchyma of the non-host plants

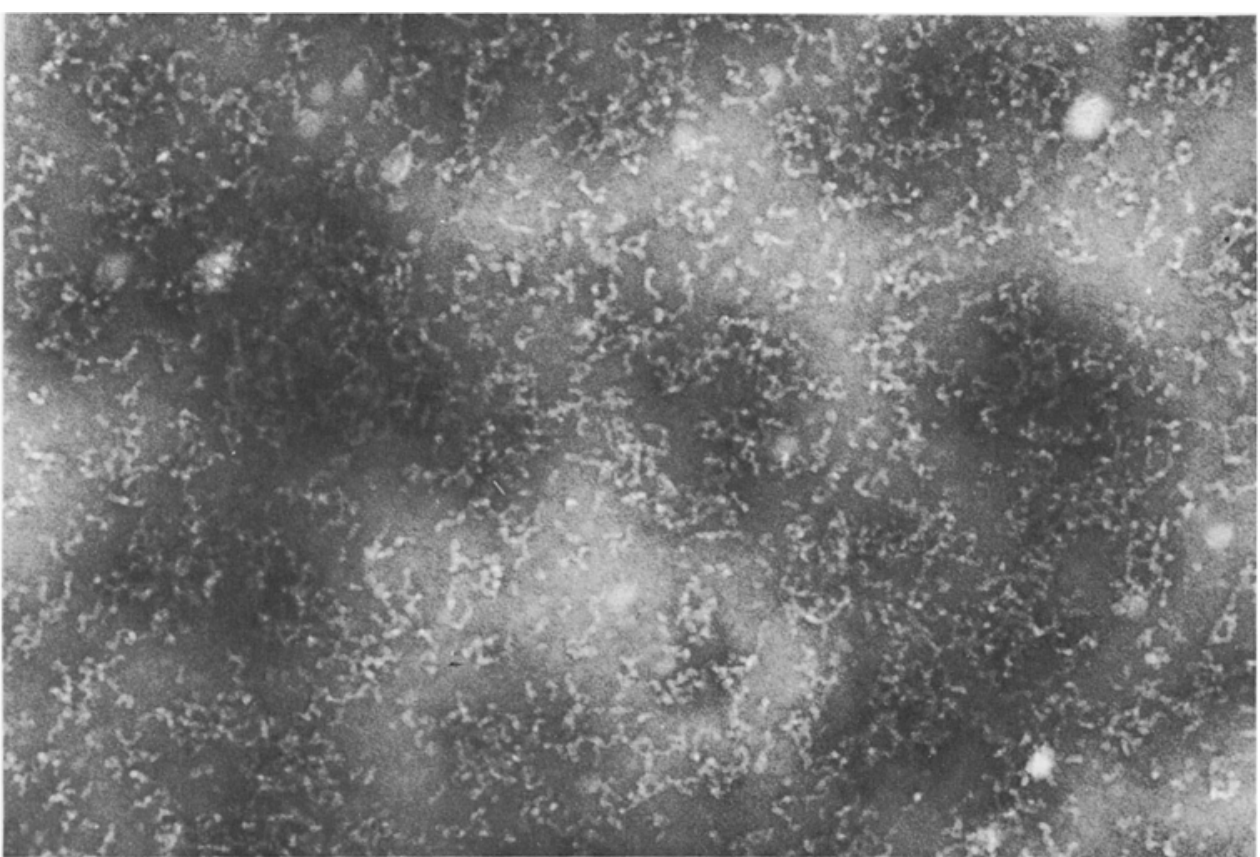

Fig. 1

Preparation of the hyphal wall material, after negative staining, $120,000 \times$ 
2
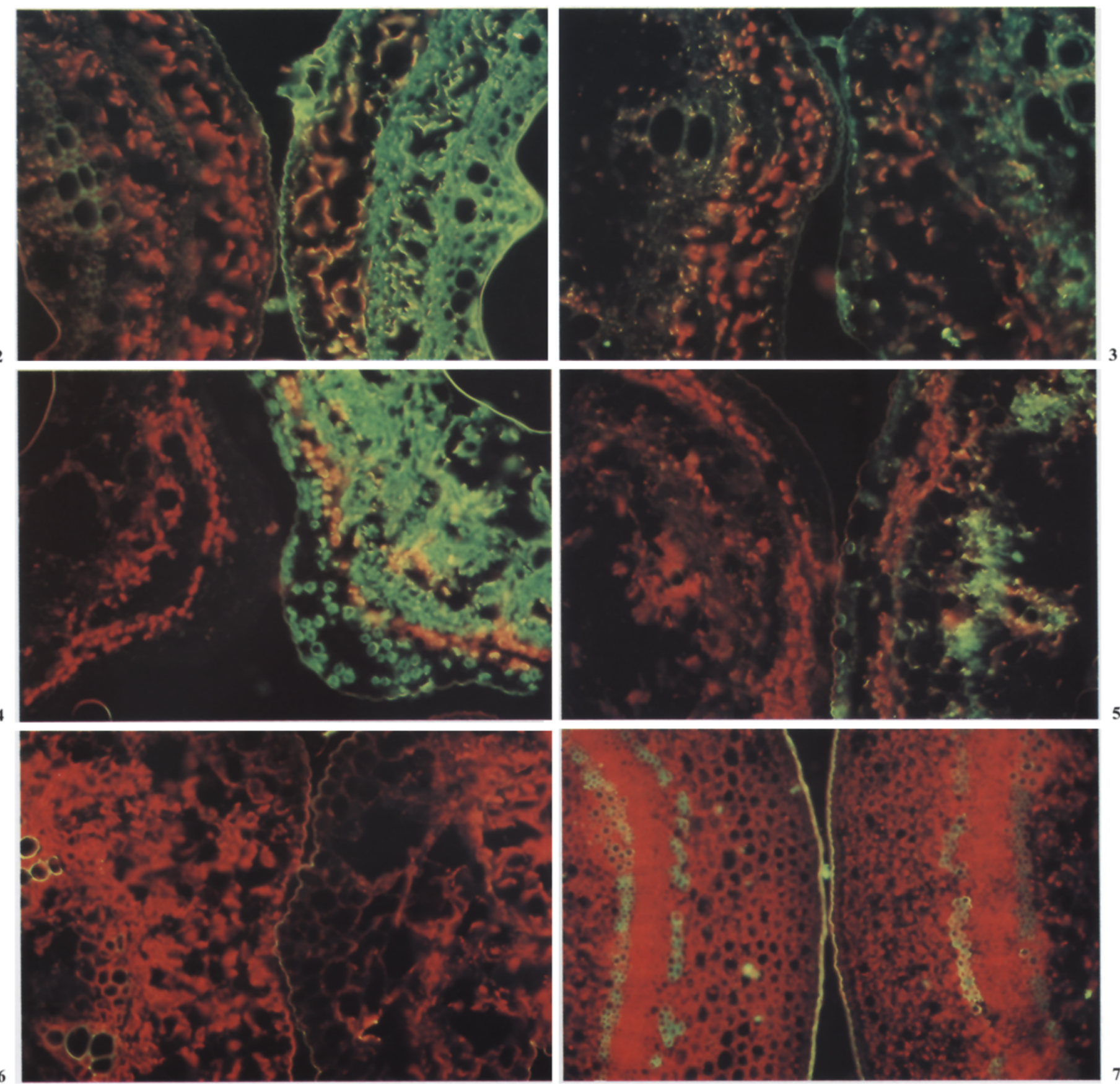

Figs. 2-7. Adhesion of FITC-labeled bean rust germ tube material to host and non-host tissue. Each figure shows two sections $(\times 120)$. At the $l e f t$, the non-incubated section with the red fluorescence of chlorophyll, yellow fluorescence of the cuticula and an yellow-green fluorescence of xylem vessels. At the right, in the incubated section, the red fluorescence of the chlorophyll was sometimes reduced either by the incubation in the warm mixture or concealed by the bright green fluorescence of the attached wall material of the bean rust fungus labeled with FITC. In the bundles, the green fluorescence was especially enhanced

Fig. 2. Phaseolus vulgaris (cv Favorit)

Fig. 3. Phaseolus vulgaris (cv Favorit), the right section was preincubated with non labeled wall material

Fig. 4. Phaseolus vulgaris (cv Golden Gate Wax, resistant)

Fig. 5. Vigna sinensis (cowpea)

Fig. 6. Phaseolus aureus (Jerusalembohne)

Fig. 7. Brassica oleracea (cv Blauer Delikatess) 
Table 1. Number of haustoria per infection hypha and staining of tissue with the labeled bean rust wall preparation in the different plants used

$\begin{array}{lll}\text { With bean rust } & \text { Haustoria/ } & \text { Staining } \\ \text { infected plant } & \text { infection } & \text { of } \\ \text { hypha } & \text { tissue }\end{array}$

Phaseolus vulgaris

cv Favorit

Phaseolus vulgaris

cv Golden Gate Wax

Phaseolus vulgaris cv 017

Phaseolus lunatus

Phaseolus aureus

Vigna sinensis

Helianthus annuus

Brassica oleracea

Hordeum vulgare

$\begin{array}{ll}0.9 & \times \times \\ 0.9 & \times \times \\ 0.9 & \times \times \\ 0.6 & \times \\ 0 & - \\ 0.5 & \times \\ 0 & - \\ 0 & - \\ 0 & -\end{array}$

$x \times=$ good staining, $x=$ weak staining, $-=$ no staining

Vigna sinensis and Phaseolus lunatus. In all other nonhost plants, no haustoria could be detected, although the infection hyphae were in contact with the mesophyll cells (Table 1).

To study the attachment of the fungal hypha to the host cell, a preparation of germ tube walls, that consisted of very short, filamentous, partly beaded particles (Fig. 1), was labeled with FITC. Freeze sections of the plants studied were incubated in this suspension. Increased green fluorescence (= staining) of the tissue after incubation was taken as an indication of fungal wall material attachment to the host cell. Figure 2 shows, at the left, a non incubated section, and at the right, a section incubated in the labeled wall material. Obviously, the bean tissue stains very well. We could not differentiate, even at higher magnifications, whether walls, cytoplasm, or any organelles showed pronounced fluorescence. The reason might be that the sections were too thick to allow a better resolution. Preincubation of the sections with nonlabeled fungal wall material reduced subsequent staining with labeled wall material (Fig. 3). Incompatible bean cultivars, such as cv 017 and cv Golden Gate Wax (Fig. 4) were stained with the same intensity as the compatible cv Favorit (Fig. 2). In non-host plants, in which fewer haustoria were found, such as cowpea (Vigna sinensis, Fig. 5) and limabean (Phaseolus lunatus) weaker staining in comparison to the sections of host plants was observed. Other non-host plants, such as the cv Jerusalembohne (Phaseolus aureus, Fig. 6), sunflower (Helianthes annuus), barley (Hordeum vulgare) and kohlrabi (Brassica oleracea) (Fig. 7), in which haustoria did not develop, did not stain (Table 1).

Since the bean rust also tries to penetrate through the stomata of bean leaf replicas (Wynn, 1976), it is obvious that the growth of the fungus on the leaf surface and its penetration into the parenchyma is influenced by a nonspecific surface stimulus. Infection structures are also formed on agar (Wolf, pers. comm.). However, no haustoria are formed even when a rust fungus can be grown under axenic conditions. The induction of haustoria apparently is an important step in the development of the fungus, but the triggering point is unknown.

Heath $(1974,1977)$ proposed that formation of haustoria might be stimulated by the host plant, but inhibited in non-host plants (see also Leath and Rowell, 1970). Our study cannot contribute experimental evidence for an inhibition factor in the non-host plants that might prevent formation of haustoria because we did not look for an eventual callose deposition in the cells near the infection hypha. Perhaps, the lack of attachment to non-host cells, as first shown by Heath (1974) for Vicia faba, infected with cowpea rust, generally accounts for the inability of the bean rust to form haustoria in non-host plants.

Obviously, a host plänt stimulates formation of haustoria. Our results propose that this stimulation is performed by a recognition between host and parasite. This recognition seems to be indicated by an attachment of our preparation of hyphal walls (i.e. their polysaccharides or both the combination of polysaccharides and proteins) to the plant cell.

This recognition is not very specific, however. Some non-host plants and the resistant host plants studied also bind wall material of the rust hypha. But in these plants haustoria were formed and there was a good correlation between attachment of the wall preparation to the plant tissue and the formation of haustoria. The decision whether these haustoria can live and function as in a compatible combination, is obviously governed by factors within the infected cell (Mendgen, 1977) that might be correlated with the metabolism of this cell (see Wheeler, 1976).

Unfortunately, this light microscope study could not clearly differentiate between staining of the cell wall, of the cytoplasm or even of the plasma membrane. Therefore, an electron microscope study with purified wall fractions is needed to give results with higher resolution that might indicate more specific interactions between susceptible and resistant plants.

The wall material used in this study was prepared very similarly to the preparation used by Hümme et al. (1978) to induce resistance against the bean rust. Hümme et al. (1978) extracted the wall fraction by autoclaving and used the clear supernatant containing carbohydrates and proteins at a ratio of $1.4: 1$ for their experiments. The components of this extract might be identical with the material attaching to the host cells. Similar wall extracts are also known to elicit a for- 
mation of phytoalexins as described by Keen et al. (1972) and more recently, for a bean pathogen, Colletotrichum lindemuthianum, (Anderson, 1978, Anderson and Albersheim, 1975). However, these elicitors are quite unspecific in relation to the fungushost plant system used and more studies are needed to find out which components of a pathogen's wall are responsible for specific and nonspecific interactions with the different plants.

Acknowledgements. I thank Prof. W. H. Fuchs, Prof. R. Heitefuss and Dr. H. H. Hoppe for reading the manuscript, Miss Elvira Reupke for technical assistance, and the Deutsche Forschungsgemeinschaft for grant Me 523/6.

\section{References}

Anderson, A. J.: Isolation from three species of Colletotrichum of glucan-containing polysaccharides that elicit browning and phytoalexin production in bean. Phytopathology 68, 189-194 (1978)

Anderson, A. J., Albersheim, P.: Host-pathogen interactions. VII. Isolation of a pathogen synthesized fraction rich in glucan, that elicits a defence response in the pathogen's host. Plant Physiol. 56, 286-291 (1975)

Bracker, C. E., Littlefield, L. J.: Structural concepts of host-pathogen interfaces. In: Fungal pathogenicity and the plant's response ( $\mathrm{J}$ W. Byrde, C. V. Cutting, eds.). London: Academic Press 1973

Costerton, J. W., Geesey, G. G., Cheng, K. J.: How bacteria stick. Sci. Am. 238, 86-95 (1978)

Dazzo, F. B., Hubbell, D. H.: Cross-reactive antigens and lectin as determinants of symbiotic specificity in the Rhizobium-clover association. Appl. Microbiol. 30, 1017-1033 (1975)

Dazzo, F. B., Yanke, W. E., Brill, W. J.: Trifoliin, a Rhizobium recognition protein from white clover. Biochim. Biophys. Acta 539, 276-286 (1978)

Goodman, R. N., Huang, Pi-Yu, White, J. A.: Ultrastructural evidence for immobilization of an incompatible bacterium, Pseudomonas pisi, in tobacco leaf tissue. Phytopathology 66, $754-764$ (1976)

Heath, M. C.: Light and electron microscope studies of the interactions of host and non-host plants with cowpea rust Uromyces phaseoli var. vignae. Physiol. Plant Pathol. 4, 403-414 (1974)

Heath, M. C.: A comparative study of non-host interactions with rust fungi. Physiol. Plant Pathol. 10, $73-88$ (1977)
Hümme, B., Hoppe, H. H., Heitefuss, R. : Resistance inducing factors from germ tube walls of uredospores of Uromyces phaseoli. Phytopathol. Z. (in press, 1978)

Joppien, S., Burger, A., Reisener, H. J.: Untersuchungen über den chemischen Aufbau von Sporen und Keimschlauchwänden der Uredosporen des Weizenrostes (Puccinia graminis var. tritici). Arch. Mikrobiol. 82, 337-352 (1972)

Kauss, H.: The possible physiological role of lectins. In: Cell wall biochemistry related to specificity in host-plant pathogen interactions (B. Solheim, J. Raa, eds.), pp. 347--360. Oslo: Universitetsforlaget 1977

Keen, N. T., Partridge, J. E., Zaki, A. I.: Pathogen-produced elicitor of a chemical defence mechanism in soybeans monogenically resistant to Phytophthora megasperma var. sojae. Phytopathology 62, 768 (1972)

Leath, K. T., Rowell, J. B.: Nutritional and inhibitory factors in the resistance of Zea mays to Puccinia graminis. Phytopathology 60, $1097-1100(1970)$

Lippincott, B. B., Lippincott, J. A. : Bacterial attachment to a specific wound site as an essential stage in tumor initiation by Agrobacterium tumefaciens. J. Bacteriol. 78, 620-628 (1969)

Mendgen, K.: Reduced Lysine uptake by bean rust haustoria in a resistant reaction. Naturwissenschaften 64, 438-439 (1977)

Mendgen, K.: Der Infektionsverlauf von Uromyces phaseoli bei anfälligen und resistenten Bohnensorten. Phytopathol. Z. (in press, 1978)

Raa, J., Robertsen, B., Solheim, B., Tronsmo, A.: Cell surface biochemistry related to specificity of pathogenesis and virulence of microorganisms. In: Cell wall biochemistry related to specificity in host-plant pathogen interactions (B. Solheim, J. Raa, eds.), pp. 11-30. Oslo: Universitetsforlaget 1977

Sequeira, L., Gaard, G., De Zoeten, G. A.: Interaction of bacteria and host cell walls: its relation to mechanisms of induced resistance. Physiol. Plant Pathol. 10, 43-50 (1977)

Sutherland, I. W.: Surface carbohydrates of the prokaryotic cell. London: Academic Press 1977

Trocha, P., Daly, J. M.: Cell walls of germinating uredospores. II. Carbohydrate polymers. Plant Physiol. 53, 527-532 (1974)

Trocha, P., Daly, J. M., Langenbach, R. J. : Cell walls of germinating uredospores. I. Amino acid and carbohydrate constituents. Plant. Physiol. 53, 519-526 (1974)

Wheeler, H. E.: Permeability alterations in diseased plants. In: Physiological plant pathology (R. Heitefuss, P. H. Williams, eds.), pp. 413-426. Berlin-Heidelber-New York: Springer 1976

Wynn, W. K.: Appressorium formation over stomates by the bean rust fungus: response to a surface contact stimulus. Phytopathology 66, 136-146 (1976)

Received May 18, 1978 